\title{
EXTRACT FROM THE ANNUAL REPORT OF THE CHIEF MEDICAL OFFICER FOR THE YEAR 1953*
}

\section{VENEREAL DISEASES}

Syphilis.-Though there has been a further fall in the number of patients attending the clinics for the first time with infections of less than one year (see Table B), this fall has been proportionately less than in recent years and in some areas the numbers have actually risen. The ratio of male to female patients treated continues to be comparatively satisfactory, having regard to the fact that a high proportion of the men attending dockside clinics were infected overseas. Generally speaking, fewer cases of early infectious syphilis are seen among seamen than in 1952, though in London this is less evident and in a few clinics the numbers show a slight rise.

EARLY SYPHILITIC INFECTIONS DEALT WITH FOR THE FIRST TIME IN 1952 AND 1953 IN TEN SAMPLE URBAN AREAS

\begin{tabular}{|c|c|c|c|c|c|c|}
\hline \multirow{2}{*}{ Area } & \multicolumn{3}{|c|}{1952} & \multicolumn{3}{|c|}{1953} \\
\hline & Males & Females & Total & Males & Females & Total \\
\hline $\begin{array}{c}\text { London Administrative } \\
\text { Area }(3,343,000)^{*}\end{array}$ & 249 & 95 & 344 & 225 & 44 & 269 \\
\hline $\begin{array}{l}\text { Merseyside (Liverpool, } \\
\text { Bootle, Birkenhead, } \\
\text { Wallasey) }(1,109,830) \\
\text { Manchester and Salford }\end{array}$ & $\mid 130$ & 22 & 152 & 78 & 14 & 92 \\
\hline $\begin{array}{l}\text { (875,700) } \\
\text { Tyneside }(463,800) \\
\text { Hull }(299,400) \\
\text { Southampton }(177,100) \\
\text { Bristol }(444,200) \\
\text { Birmingham }(1,118,500) \\
\text { Leeds and Bradford }\end{array}$ & $\begin{array}{l}43 \\
32 \\
25 \\
17 \\
25 \\
27\end{array}$ & $\begin{array}{r}24 \\
18 \\
16 \\
5 \\
7 \\
12\end{array}$ & $\begin{array}{l}67 \\
50 \\
41 \\
22 \\
32 \\
39\end{array}$ & $\begin{array}{l}20 \\
13 \\
21 \\
22 \\
22 \\
38\end{array}$ & $\begin{array}{r}13 \\
15 \\
16 \\
2 \\
2 \\
13\end{array}$ & $\begin{array}{l}33 \\
28 \\
37 \\
24 \\
24 \\
51\end{array}$ \\
\hline $\begin{array}{l}(792,100) \\
\text { Sheffield }(507,600)\end{array}$ & $\begin{array}{r}16 \\
1\end{array}$ & $\begin{array}{r}10 \\
8\end{array}$ & $\begin{array}{r}26 \\
9\end{array}$ & $\begin{array}{r}8 \\
14\end{array}$ & $\begin{array}{r}5 \\
10\end{array}$ & $\begin{array}{l}13 \\
24\end{array}$ \\
\hline
\end{tabular}

* The figures in brackets are the estimated population at 30 June, 1953.

The figures for infantile congenital syphilis are only slightly less than in 1952 (95 as against 110) and an improvement in this record low number can only be expected if the practice of ante-natal blood testing during each pregnancy becomes more widespread. The physician in charge of an important venereal diseases clinic in the north of England reports that such cases as he now sees are almost invariably the children of mothers for whose confinements general practitioners have been responsible, and who have not attended the ante-natal clinics of the local authorities. The number of cases of

* Part II of the Report of the Ministry of Health for the year ended 31st December, 1953. Cmd.9307. p. 67 and Appendix C, p. 250. congenital syphilis among older children and adults has fallen from 839 to 749 .

Though many patients in the later stages of syphilis are treated elsewhere than in the venereal diseases clinics, the clinic figures are of interest in that they show a steep fall in the number of women suffering from latent and what may be called " benign" late syphilis as distinct from those with cardio-vascular or nervous manifestations. Many of the former are referred from the ante-natal clinics of local authorities, and it may be that the decline in their numbers is not unconnected with the increase in the number of pregnant women under the care of the family doctor and on whom routine blood tests are not usually carried out. The fact that there has been no significant fall in neurosyphilis in women and an actual rise in those with cardio-vascular involvement, emphasizes the need for an extension of routine blood testing if these often fatal complications are to be avoided.

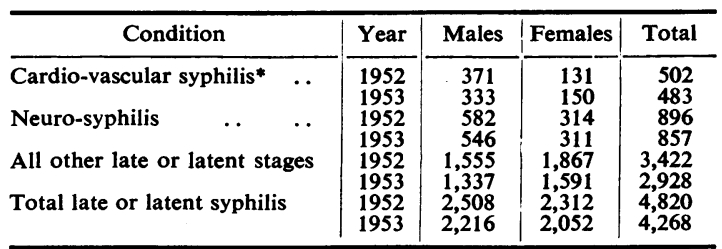

* Patients suffering from cardio-vascular syphilis who are also suffering from syphilis of other systems are recorded as suffering from cardio-vascular syphilis alone.

As well as those attending for the first time in 1953, 17,863 males and 18,580 females remained under treatment or observation for syphilis from former years.

Certified deaths in England and Wales from general paralysis of the insane, tabes dorsalis, and aneurysm of the aorta (excluding cases specified as non-syphilitic) are shown in Table E. In spite of the fall in the figure for general paralysis of the insane in females, there is little or no significant change in these numbers which serve to some extent as an index of the prevalence of potentially lethal syphilis.

Gonorrhoea.-There has been a further slight increase in the clinic incidence of gonorrhoea which is due to a rise in the number of new female patients attending the clinics for the first time. This rise is 
welcome in that it may indicate a small improvement in the results of contact tracing in this disease.

Though there is no certain evidence that penicillinresistant gonococci are in circulation, there is an impression among some venereologists that relapses are rather less uncommon than they were a few years ago. The difficulty, and in many cases the impossibility, of distinguishing relapse from reinfection will be appreciated.

Other Venereal Diseases.-Three hundred and fifty-six cases of chancroid were seen at the clinics in 1953, as against 403 in 1952, and 76 cases of lymphogranuloma venereum (Nicholas Favre), seven more than in 1952. Two cases of granuloma inguinale (Donovan) were also reported.

There has been a marked increase in nongonococcal urethritis in men, new cases having risen from 11,552 in 1952 to 13,157 in 1953 . The investigation and treatment of these patients and their female consorts is time-consuming and often discouraging, as relapse after apparent cure is common. It may be significant that the number of women attending the clinics for the first time with various " non-specific" conditions, the majority of whom complain of vaginal discharge, has risen from 8,916 in 1952 to 9,834 in 1953 . It is becoming increasingly realized that it is equally important to investigate and treat the female consorts of men suffering from non-gonococcal urethritis as of those with gonococcal infections.

The symptoms of non-specific venereal urethritis are often minimal and it is probable that many persons are infected unknowingly and consequently are never treated.

Other Conditions treated at the Clinics.-There has again been an increase in the number of men as well as women attending the clinics suffering from various conditions with a real or imaginary venereal background. These included balanitis, genital "warts," scabies, pediculosis, trichomonas infestation, moniliasis, and other conditions often due to a lack of personal hygiene. In addition to 23,400 of these patients a further 36,231 were found only to need reassurance.

Therapy.-Penicillin continues to be the therapeutic standby for syphilis in all its stages, as well as for gonorrhoea, and there seems little likelihood that it will be superseded by any of the newer antibiotics in the routine treatment of these diseases. The new penicillin salts, $\mathrm{N}, \mathrm{N}^{1}$-Dibenzylethylenediamine penicillin (diamine penicillin) and $\mathrm{N}$-benzyl B phenylethylamine penicillin (Benathamine penicillin), which give longer therapeutic blood levels than those obtainable with other preparations, are now under clinical trial in syphilis and yaws. If their early promise is fulfilled, they should be of special value in those underdeveloped areas overseas, where a "one-shot" treatment is particularly called for.

The treatment of most cases of non-gonococcal urethritis continues to be empirical, though streptomycin, aureomycin, terramycin, and sulphonamides are all more or less successful in shortening an attack, if not always in curing the disease. Relapse is all too common and the proper management of the condition cannot be expected until the causal organism or organisms have been identified.

Social Aspects.-The necessity for social work in venereal diseases clinics is universally recognized, and it should be appreciated that this does not begin and end with the tracing of contacts and defaulters from treatment. The clinic doctor rightly spends much of his time explaining the implications of the disease to the patient, allaying anxiety and helping in the solution of the many difficulties, domestic and other, that are inevitably associated with these infections. Assistance in this side of his work is just as necessary as is the technical help given by his nursing staff and in most clinics the services of a hospital almoner or one of the health visitors on the staff of the local medical officer of health are available for this purpose. It is hoped that in the near future this type of help will be universally attainable.

At the request of the Prison Commissioners, the services of a whole-time welfare officer have been made available to the venereologist at Holloway women's prison by the medical officer of health to the London County Council. Despite many difficulties, good results have been achieved in tracing the contacts of infected prisoners and in overcoming their reluctance to attend hospital outpatient clinics on discharge. Such social work among a section of the population particularly liable to be infected should do much towards reducing an inevitable reservoir of infection.

The Present Position.-The increased prevalence of venereal urethritis in men and of gonorrhoea in women and also the fact that in some areas the clinic incidence of early infectious syphilis is no longer falling, forbids any complacency and underlines the need for vigilance, especially in seaport cities. Here are the main reservoirs of infection, fortunately still half empty, but which would rapidly fill in the event of a national emergency. The tracing of contacts, with all its difficulties and disappointments, is now without doubt the most important single measure in the control of the spread of infection. 
APPENDIX

TABLE A

NUMBER OF CASES (IN ALl STAGES) DEALT WITH FOR THE FIRST TIME AT ANY CENTRE*

\begin{tabular}{|c|c|c|c|c|c|c|c|}
\hline Sex & Year & Syphilis & $\begin{array}{c}\text { Soft } \\
\text { Chancre }\end{array}$ & Gonorrhoea & Total V.D. & $\begin{array}{c}\text { Other } \\
\text { Conditions }\end{array}$ & $\begin{array}{c}\text { Total } \\
\text { Attendances }\end{array}$ \\
\hline Males & $\begin{array}{l}1925 \\
1926 \\
1927 \\
1928 \\
1929 \\
1930 \\
1931 \\
1932 \\
1933 \\
1934 \\
1935 \\
1936 \\
1937 \\
1938 \\
1939 \\
1940 \\
1941 \\
1942 \\
1943 \\
1944 \\
1945 \\
1946 \\
1947 \\
1948 \\
1949 \\
1950 \\
1951 \\
1952 \\
1953 \\
\end{array}$ & $\begin{array}{r}11,782 \\
12,118 \\
12,393 \\
12,051 \\
11,538 \\
11,967 \\
11,285 \\
11,032 \\
10,738 \\
9,615 \\
8,596 \\
8,224 \\
8,069 \\
7,832 \\
7,273 \\
7,093 \\
7,790 \\
8,529 \\
8,790 \\
7,667 \\
8,134 \\
13,803 \\
11,699 \\
9,780 \\
7,826 \\
5,979 \\
4,506 \\
3,760 \\
3,272 \\
\end{array}$ & $\begin{array}{r}1,048 \\
1,070 \\
986 \\
1,053 \\
1,202 \\
1,244 \\
1,042 \\
845 \\
826 \\
876 \\
1,011 \\
880 \\
824 \\
889 \\
827 \\
887 \\
1,017 \\
969 \\
773 \\
628 \\
589 \\
994 \\
776 \\
706 \\
543 \\
433 \\
437 \\
389 \\
347 \\
\end{array}$ & $\begin{array}{l}24,398 \\
25,3535 \\
28,195 \\
30,425 \\
31,810 \\
32,217 \\
29,310 \\
28,179 \\
29,169 \\
28,787 \\
27,506 \\
28,137 \\
29,250 \\
27,947 \\
24,811 \\
21,057 \\
20,572 \\
17,956 \\
18,215 \\
16,629 \\
21,280 \\
36,912 \\
29,647 \\
25,006 \\
20,366 \\
17,007 \\
14,975 \\
15,510 \\
15,242 \\
\end{array}$ & $\begin{array}{l}37,228 \\
38,723 \\
41,574 \\
43,529 \\
44,550 \\
45,428 \\
41,637 \\
40,056 \\
40,733 \\
39,278 \\
37,113 \\
37,241 \\
38,143 \\
36,668 \\
32,911 \\
29,037 \\
29,379 \\
27,454 \\
27,778 \\
24,924 \\
30,003 \\
51,709 \\
42,122 \\
35,492 \\
28,735 \\
23,419 \\
19,918 \\
19,659 \\
18,861\end{array}$ & $\begin{array}{l}13,384 \\
14,269 \\
16,192 \\
17,959 \\
17,970 \\
19,724 \\
19,838 \\
20,745 \\
20,918 \\
23,639 \\
23,605 \\
23,393 \\
24,263 \\
26,081 \\
24,324 \\
20,005 \\
20,476 \\
22,302 \\
36,868 \\
34,123 \\
42,110 \\
70,239 \\
53,766 \\
56,435 \\
52,526 \\
55,068 \\
49,770 \\
50,353 \dagger \\
52,414\end{array}$ & $\begin{array}{r}1,248,157 \\
1,500,074 \\
1,621,409 \\
1,794,205 \\
1,958,095 \\
2,119,257 \\
2,251,710 \\
2,322,982 \\
2,396,696 \\
2,488,538 \\
2,474,531 \\
2,457,595 \\
2,446,730 \\
2,218,584 \\
1,587,111 \\
1,170,412 \\
1,065,114 \\
1,071,664 \\
1,082,427 \\
973,810 \\
912,571 \\
1,279,743 \\
1,101,970 \\
995,724 \\
860,960 \\
780,451 \\
677,251 \\
650,014 \\
622,368\end{array}$ \\
\hline Females & $\begin{array}{l}1925 \\
1926 \\
1927 \\
1928 \\
1929 \\
1930 \\
1931 \\
1932 \\
1933 \\
1934 \\
1935 \\
1936 \\
1937 \\
1938 \\
1939 \\
1940 \\
1941 \\
1942 \\
1943 \\
1944 \\
1945 \\
1946 \\
1947 \\
1948 \\
1947 \\
1950 \\
1951 \\
1952 \\
1953\end{array}$ & $\begin{array}{r}7,385 \\
7,133 \\
7,553 \\
7,090 \\
6,586 \\
6,916 \\
6,827 \\
6,461 \\
6,029 \\
5,838 \\
5,565 \\
5,128 \\
5,165 \\
4,986 \\
4,605 \\
4,226 \\
4,972 \\
6,542 \\
7,960 \\
8,251 \\
8,508 \\
10,075 \\
8,438 \\
7,349 \\
5,873 \\
4,988 \\
3,926 \\
3,, 362 \\
2,914\end{array}$ & $\begin{array}{r}27 \\
21 \\
20 \\
28 \\
22 \\
17 \\
20 \\
29 \\
22 \\
10 \\
16 \\
29 \\
15 \\
15 \\
11 \\
21 \\
20 \\
27 \\
32 \\
28 \\
29 \\
34 \\
27 \\
21 \\
19 \\
17 \\
16 \\
14 \\
9\end{array}$ & $\begin{array}{r}6,120 \\
6,416 \\
6,809 \\
7,810 \\
7,798 \\
7,939 \\
7,697 \\
7,677 \\
8,583 \\
8,199 \\
7,732 \\
7,715 \\
7,787 \\
7,746 \\
6,489 \\
5,882 \\
7,314 \\
8,413 \\
10,043 \\
10,646 \\
11,603 \\
10,431 \\
7,019 \\
5,306 \\
4,121 \\
3,497 \\
3,089 \\
3,585 \\
4,021\end{array}$ & $\begin{array}{r}13,532 \\
13,570 \\
14,382 \\
14,928 \\
14,406 \\
14,872 \\
14,544 \\
14,167 \\
14,634 \\
14,047 \\
13,313 \\
12,872 \\
12,967 \\
12,747 \\
11,105 \\
10,129 \\
12,306 \\
14,982 \\
18,035 \\
18,925 \\
20,140 \\
20,540 \\
15,484 \\
12,676 \\
10,013 \\
8,502 \\
7,031 \\
6,961 \\
6,944\end{array}$ & $\begin{array}{r}7,287 \\
8,082 \\
8,705 \\
9,492 \\
9,595 \\
10,960 \\
11,402 \\
11,586 \\
11,223 \\
12,672 \\
12,625 \\
13,231 \\
14,002 \\
15,182 \\
14,684 \\
12,881 \\
15,068 \\
20,190 \\
34,681 \\
38,566 \\
41,524 \\
35,475 \\
29,314 \\
27,462 \\
24,801 \\
23,840 \\
21,160 \\
20,682 \\
20,452\end{array}$ & $\begin{array}{l}470,991 \\
507,989 \\
558,298 \\
628,544 \\
646,122 \\
697,938 \\
741,051 \\
786,192 \\
855,627 \\
918,462 \\
924,147 \\
902,733 \\
895,841 \\
900,747 \\
723,455 \\
597,321 \\
593,223 \\
704,076 \\
868,097 \\
916,116 \\
911,974 \\
864,682 \\
721,017 \\
663,503 \\
585,555 \\
529,825 \\
467,412 \\
427,977 \\
398,902\end{array}$ \\
\hline
\end{tabular}

*Excludes cases transferred from centre to centre. IIncluding non-gonococcal urethritis. 
TABLE B

CASES OF ACQUIRED SYPHILIS IN TABLE A, WITH INFECTIONS OF LESS THAN ONE YEAR

\begin{tabular}{|c|c|c|c|c|}
\hline \multirow{2}{*}{ Year } & \multicolumn{2}{|c|}{ Number } & \multicolumn{2}{|c|}{ Per cent. of Table A Cases } \\
\hline & Males & Females & Males & Females \\
\hline 1931 & 6,421 & 2,683 & 56.9 & $37 \cdot 3$ \\
\hline $\begin{array}{l}1932 \\
1933\end{array}$ & $\begin{array}{l}6,196 \\
5,949\end{array}$ & $\begin{array}{l}2,532 \\
2,141\end{array}$ & $\begin{array}{l}56 \cdot 2 \\
55 \cdot 4\end{array}$ & $\begin{array}{l}39 \cdot 2 \\
35 \cdot 5\end{array}$ \\
\hline 1934 & 4,888 & 2,030 & 50.8 & 34.8 \\
\hline 1935 & 4,226 & 1,745 & $49 \cdot 2$ & 31.4 \\
\hline 1936 & 4,033 & 1,642 & $49 \cdot 0$ & $32 \cdot 0$ \\
\hline 1937 & 3,986 & 1,647 & $49 \cdot 4$ & 31.9 \\
\hline 1938 & 3,744 & 1,494 & 47.8 & 30.0 \\
\hline 1939 & 3,574 & 1,412 & $49 \cdot 1$ & $30 \cdot 7$ \\
\hline 1940 & 4,029 & 1,582 & 56.8 & $37 \cdot 4$ \\
\hline 1941 & 5,023 & 2,309 & $64 \cdot 5$ & $46 \cdot 4$ \\
\hline 1942 & 5,470 & 3,576 & $64 \cdot 1$ & $54 \cdot 7$ \\
\hline 1943 & 5,159 & 4,483 & 58.7 & $56 \cdot 3$ \\
\hline 1944 & 4,384 & 4,934 & $57 \cdot 2$ & 59.8 \\
\hline 1945 & 5,214 & 5,527 & $64 \cdot 1$ & 64.9 \\
\hline 1946 & 10,705 & 6,970 & 77.6 & $69 \cdot 2$ \\
\hline 1947 & 8,750 & 5,416 & 74.8 & $64 \cdot 2$ \\
\hline 1948 & 6,603 & 4,034 & $67 \cdot 5$ & 54.9 \\
\hline 1949 & 4,392 & 2,420 & 56.1 & $41 \cdot 2$ \\
\hline 1950 & 2,678 & 1,465 & $44 \cdot 8$ & $29 \cdot 4$ \\
\hline 1951 & 1,498 & 774 & $33 \cdot 2$ & $19 \cdot 7$ \\
\hline 1952 & 891 & 462 & $23 \cdot 7$ & 13.7 \\
\hline 1953 & 755 & 319 & $23 \cdot 0$ & $10 \cdot 9$ \\
\hline
\end{tabular}

TABLE C

CASES OF CONGENITAL SYPHILIS DEALT WITH FOR THE FIRST TIME AT THE TREATMENT CENTRES

\begin{tabular}{|c|c|c|c|c|c|}
\hline Year & $\begin{array}{l}\text { Under } \\
1 \text { Year }\end{array}$ & $\begin{array}{c}1 \text { and } \\
\text { Under } \\
5 \text { Years }\end{array}$ & $\begin{array}{c}5 \text { and } \\
\text { Under } \\
15 \text { Years }\end{array}$ & $\begin{array}{l}15 \text { Years } \\
\text { and } \\
\text { Over }\end{array}$ & Totals \\
\hline $\begin{array}{l}1931 \\
1932 \\
1933 \\
1934 \\
1935 \\
1936 \\
1937 \\
1938 \\
1939 \\
1940 \\
1941 \\
1942 \\
1943 \\
1944 \\
1945 \\
1946 \\
1947 \\
1948 \\
1949 \\
1950 \\
1951 \\
1952 \\
1953\end{array}$ & $\begin{array}{r}339 \\
302 \\
305 \\
296 \\
251 \\
241 \\
211 \\
216 \\
217 \\
191 \\
223 \\
245 \\
310 \\
346 \\
326 \\
363 \\
343 \\
372 \\
355 \\
227 \\
156 \\
110 \\
95\end{array}$ & $\begin{array}{r}204 \\
180 \\
157 \\
165 \\
165 \\
132 \\
144 \\
123 \\
125 \\
101 \\
90 \\
122 \\
129 \\
113 \\
83 \\
103 \\
120 \\
142 \\
118 \\
141 \\
89 \\
101 \\
77\end{array}$ & $\begin{array}{l}974 \\
857 \\
774 \\
708 \\
671 \\
600 \\
534 \\
448 \\
406 \\
357 \\
321 \\
309 \\
348 \\
271 \\
210 \\
215 \\
214 \\
215 \\
197 \\
203 \\
198 \\
191 \\
152\end{array}$ & $\begin{array}{l}922 \\
805 \\
780 \\
839 \\
944 \\
935 \\
940 \\
951 \\
866 \\
709 \\
746 \\
788 \\
940 \\
822 \\
736 \\
701 \\
676 \\
678 \\
747 \\
652 \\
684 \\
547 \\
520\end{array}$ & $\begin{array}{r}2,439 \\
2,144 \\
2,016 \\
2,008 \\
2,031 \\
1,908 \\
1,829 \\
1,738 \\
1,614 \\
1,358 \\
1,380 \\
1,464 \\
1,727 \\
1,552 \\
1,355 \\
1,382 \\
1,353 \\
1,407 \\
1,417 \\
1,223 \\
1,127 \\
949 \\
844\end{array}$ \\
\hline
\end{tabular}

TABLE D

DEATH RATES PER 1,000 LIVE BIRTHS, OF INFANTS UNDER 1 YEAR CERTIFIED AS DUE TO CONGENITAL SYPHILIS

\begin{tabular}{|c|c|c|c|c|c|c|c|}
\hline Year & Rate & Year & Rate & Year & Rate & Year & Rate \\
\hline $\begin{array}{l}1912 \\
1913 \\
1914 \\
1915 \\
1916 \\
1917 \\
1918 \\
1919 \\
1921 \\
1922 \\
1923\end{array}$ & $\begin{array}{l}1.34 \\
1.46 \\
1.55 \\
1.44 \\
1.57 \\
2.03 \\
1.90 \\
1.76 \\
1.51 \\
1.43 \\
1.12 \\
1.05\end{array}$ & $\begin{array}{l}1924 \\
1925 \\
1926 \\
1927 \\
1928 \\
1929 \\
1930 \\
1931 \\
1932 \\
1933 \\
1934 \\
1935\end{array}$ & $\begin{array}{l}0.91 \\
0.82 \\
0.84 \\
0.77 \\
0.71 \\
0.64 \\
0.55 \\
0.45 \\
0.42 \\
0.35 \\
0.30 \\
0.26\end{array}$ & $\begin{array}{l}1936 \\
1937 \\
1938 \\
1939 \\
1940 \\
1941 \\
1942 \\
1943 \\
1944 \\
1945 \\
1946 \\
1947\end{array}$ & $\begin{array}{l}0.24 \\
0.19 \\
0.18 \\
0.17 \\
0.16 \\
0.21 \\
0.19 \\
0.23 \\
0.16 \\
0.15 \\
0.15 \\
0.09\end{array}$ & $\begin{array}{l}1948 \\
1949 \\
1950^{*} \\
1951^{*} \\
1952^{*} \\
1953^{*}\end{array}$ & $\begin{array}{l}0.09 \\
0.08 \\
0.04 \\
0.03 \\
0.03 \\
0.01\end{array}$ \\
\hline
\end{tabular}

Rates for years 1931-1949 are according to the 1940 classification (5th Revision). For 1912-1930 the rates need to be multiplied by the conversion ratio 0.857 for approximate comparability.

${ }^{*}$ For 1950-1953, No. 020.2 in International List (6th Revision).

\section{TABLE E}

DEATHS FROM GENERAL PARALYSIS OF THE INSANE, TABES DORSALIS, AND ANEURYSM OF THE AORTA

\begin{tabular}{l|c|c|c|c|c|c}
\hline \multirow{2}{*}{ Years } & \multicolumn{2}{|c|}{ G.P.I. } & \multicolumn{2}{c|}{$\begin{array}{c}\text { Tabes } \\
\text { Dorsalis }\end{array}$} & \multicolumn{2}{c}{$\begin{array}{c}\text { Aneurysm of } \\
\text { Aorta* }\end{array}$} \\
\cline { 2 - 6 } & Males & Females & Males & Females & Males & Females \\
\hline $1911-20$ & 1,697 & 383 & 592 & 106 & 838 & 208 \\
$1921-30$ & 1,204 & 277 & 631 & 127 & 860 & 249 \\
$1931-35$ & 819 & 240 & 566 & 125 & 969 & 393 \\
$1936-39$ & 625 & 227 & 471 & 106 & 1,017 & 531 \\
\hline $1940-44$ & 482 & 167 & 270 & 71 & 467 & 158 \\
$1945-49$ & 258 & 101 & 157 & 41 & 485 & 166 \\
1946 & 314 & 127 & 178 & 54 & 495 & 156 \\
1947 & 283 & 116 & 164 & 44 & 502 & 177 \\
1948 & 205 & 66 & 111 & 32 & 478 & 169 \\
1949 & 161 & 65 & 114 & 20 & 515 & 191 \\
1950 & 111 & 56 & 99 & 24 & 430 & 225 \\
1951 & 121 & 47 & 111 & 32 & 475 & 204 \\
1952 & 78 & 45 & 100 & 27 & 435 & 222 \\
1953 & 91 & 26 & 87 & 26 & 408 & 190 \\
\hline
\end{tabular}

The averages for the years 1911 to 1939 are based on the 4th Revision of the International List. Figures for the years 1940 to 1953 are according to the 6th Revision.

Non-civilian deaths are excluded from the table from 3rd September, 1939, until 1949 for males, and from 1st June, 1941, until 1949 for females.

*For years 1911 to 1939 :-

"Aneurysm" (code 96) of the 4th Revision List, based on arbitrary rules of assignment.

For years 1940 and after :-

"Aneurysm of Aorta" (code 022) of the 6th Revision List, based on assignment by the certifying medical practitioner. Aortic Aneurysm specified as "non-syphilitic" or "dissecting" is no longer included in this heading.

\begin{tabular}{|c|c|c|c|c|c|c|c|}
\hline \multirow{2}{*}{ Specimens Examined } & \multicolumn{2}{|c|}{ Microscopical for } & \multirow{2}{*}{$\begin{array}{l}\text { Cultural for } \\
\text { Gonorrhoea }\end{array}$} & \multicolumn{2}{|c|}{ Serum Tests for } & \multirow{2}{*}{$\begin{array}{l}\text { Cerebro- } \\
\text { spinal } \\
\text { Fluid }\end{array}$} & \multirow{2}{*}{$\begin{array}{c}\text { Other } \\
\text { Pathological } \\
\text { Investigations }\end{array}$} \\
\hline & T. pallida & Gonococci & & Syphilis & Gonorrhoea & & \\
\hline (a) In Treatment Centres & 5,822 & 94,295 & 2,603 & 3,393 & 648 & 476 & 35,159 \\
\hline $\begin{array}{l}\text { (b) Sent by the Treatment Centres for } \\
\text { Examination in Associated } \\
\text { Laboratories }\end{array}$ & 436 & 70,312 & 77,727 & 291,081 & 58,152 & 4,466 & 18,134 \\
\hline
\end{tabular}

